\title{
Popioły i zbliżenia Materialność śladów Zagłady w fotografii
}

\section{Ashes and Close-ups. Material Traces of the Shoah in Photography}

Abstract: The text aims to draw a link between the concretization of the memory of the Holocaust and the affective effect of photography and experimental artistic techniques employing photography. The main argument is that focusing on the materiality of experiencing the physical traces of Shoah, as well as the structure and tangibility of the artistic gesture and materials used in the artistic process, can activate the affective potential of a "feeling witness" or "wit(h)ness" in both the artist and the spectator. To do that, it is necessary to transform the objectifying gaze into a look that touches and feels. The article analyses examples of artistic / photographic works that seek to mobilise this kind of look by reaching for the concrete tactility of ashes - both as a figure, as artistic material and as physical presence that can leave its imprint on the photographic film: Elżbieta Janicka's series Miejsca nieparzyste / The Odd Places, and a photograph from Wojciech Wilczyk's series Powiększenia / Blow-ups. Theorising the possibility of making an analogy between the process of working through the traumatic event in an act of artistic creativity and incorporating the ashes into a non-phallic order of signification, the text also refers to Bracha L. Ettinger's notion of Transcriptum both in her theoretical elaboration of the term and her art.

Keywords: trauma, Holocaust, photography, Transcriptum

Wydaje się, że ostatnie półwiecze przyzwyczaiło nas do określonego sposobu reprezentacji Zagłady, zamykającego się w estetyce minimalistycznych metonimii. Sztuka traktująca o Szoa wpisuje się, jak pisze Adam Mazur, w jeden z dwóch uproszczonych modeli: albo wykorzystuje tradycyjne formy przedstawienia, albo odwołuje się do spuścizny awangardy, szukając nowych form ${ }^{1}$ do zmierzenia się z tematem, który sam w sobie wymyka się reprezentacji. Mazur przywołuje nazwiska artystów, którzy uciekają się do abstrakcji, takich jak Mark Rothko, Anselm Kiefer, Julian Pałka, Jonasz Stern, Tadeusz Kantor czy Mirosław Bałka, a jednocześnie zwraca uwagę, iż nurt ten na niespotykaną wcześniej skalę wykorzystuje fotografię jako źródło wizualnego świadectwa Zagłady. Mazur wymienia w tym kontekście Gerharda Richtera, Christiana Boltanskiego, Borysa Michajłowa

1. Adam Mazur, "Negatywne świadectwo. Fotograficzna konkretyzacja pamięci Holokaustu", Teksty Drugie nr 5, 2004, 207. 
i Zbigniewa Liberę², a należy z pewnością dodać jeszcze twórców z kręgu zwrotu archiwalnego, którzy wykorzystują technikę i materiały fotograficzne, łącząc je z innymi technikami, chociażby - oprócz wspomnianego Richtera - również Jochena Gerza czy Brachę Ettinger (o której będzie mowa w dalszej części niniejszego tekstu). W kanonie powojennej polskiej sztuki traktującej o Zagładzie najczęściej chyba przywoływaną pracą w kontekście łączenia abstrakcji z fotografią jest cykl kolaży Władysława Strzemińskiego Moim przyjaciołom Żydom (1945-1947). W niniejszym tekście będę z kolei wracać jeszcze do fotografii Wojciecha Wilczyka (skupiając się na jednej z prac prezentowanych na wystawie Widok zza bliska. Inne oblicza Zagłady), Elżbiety Janickiej (seria fotografii Miejsca nieparzyste) oraz malarstwa Brachy Ettinger (w kontekście wypracowanej przez nią techniki kopiowania i zamalowywania archiwalnych zdjęć). Zwrot ku fotografii jako symptom odwrotu od przedstawienia tylko pozornie jest tu paradoksalny. Owszem, intuicyjnie zwykliśmy lokować fotografię raczej po stronie reprezentacji i metonimii niż abstrakcji i metafory, ale to właśnie metonimiczność tego medium pozwala uniknąć nachalnej symbolizacji, która zdaje się zwyczajowo przyjętym decorum realizacji upamiętniających Holokaust.

Temat Zagłady zajmuje dziś artystów, dla których pamięć o niej jest wyłącznie pamięcią zapośredniczoną. Siłą rzeczy ich "powroty" są więc weryfikacją widzialnych tropów, śladów, znaków i próbą uporania się z ich ładunkiem znaczeniowym, ale także mechanizmami ich funkcjonowania w obiegu wizualnym - a zatem często również ich przezroczystością i pozorną neutralnością ${ }^{3}$ Mazur pisze: "Łączność z wydarzeniami przynależnymi historii, takimi jak Zagłada Żydów ostateczne została zapośredniczona przez kulturę, a więc i sztukę"4. Wszechobecność i powtarzalność pewnych konotacji-symboli (takich jak na przykład bydlęce wagony, tory, drut kolczasty, komin, włosy, pasiak, walizka ${ }^{5}$ itd.) w polu wizualnym polskiej kultury została utrwalona przez rozmaite dyskursy widzialności: od artystycznych i medialnych, przez podręcznikowo-dydaktyczne, po komercyjno-turystyczne. Te przedstawienia wpisują się w wypracowane przez ostatnie 70 lat "decorum

2. Mazur, Negatywne świadectwo..., 207.

3. Temat wszechobecności śladów Holokaustu, które stają się wręcz przezroczyste, podejmują wypowiedzi artystów fotografików, w tym głośne w ostatnich latach projekty Łukasz Baksika Macewy codziennego użytku (2008-2011), Wojciecha Wilczyka Niewinne oko nie istnieje (2009) oraz opisana w niniejszym tekście seria Elżbiety Janickiej Miejsca nieparzyste (2003-2004).

4. Mazur, Negatywne świadectwo..., 211.

5. O tropach i śladach kształtujących polską pamięć Zagłady, nie tylko wizualnych, również tych mniej oczywistych, traktuje znakomita książka Ślady Holokaustu w imaginarium kultury polskiej pod redakcją Justyny Kowalskiej-Leder, Pawła Dobrosielskiego, Iwony Kurz i Małgorzaty Szpakowskiej (Warszawa: Wydawnictwo Krytyki Politycznej, 2017). 
reprezentacji Holokaustu"6, w którym, jak twierdzi Roma Sendyka, akceptowalny jest tylko tryb dokumentalny estetyka minimalizmu i monochromu? ${ }^{7}$. Jednocześnie mamy do czynienia ze swoistym paradoksem, który stanowi oś rozważań niniejszego tekstu: w obliczu silnie skonwencjonalizowanych przedstawień Zagłady, tych wszystkich odcieleśnionych pomników, podręczników, pocztówek, reklam wycieczek i szkolnych gazetek, to właśnie fotografia często zdaje się być odpowiedzią na poszukiwanie materialnej, taktylnej wręcz łączności z doświadczeniem Szoa ${ }^{8}$.

Jeśli nachalna symbolizacja jest jedną ze strategii ucieczkowych - sposobem, by nie dotknąć bolesnego miejsca w zbiorowej pamięci - to widoczny w ostatnim dziesięcioleciu "zwrot afektywny"9 w polskiej myśli poświęconej traumie i pamięci o Zagładzie można uznać za przejaw potrzeby nawiązania namacalnego kontaktu z niezabliźnioną raną traumatycznej pamięci, która nigdy nie mogła zostać należycie przepracowana. Co więcej, uważam, że to właśnie fotografia jest często narzędziem umożliwiającym dotknięcie tej rany. Materialność fotografii jako techniki, kontakt artystki lub artysty z fizyczną strukturą materiału, może skutkować przywróceniem czucia w zdrętwiałych strukturach pamięci, w zmartwiałych maszyneriach tworzenia znaczenia. Przykłady prac, które omawiam poniżej, wyraźnie pokazują jednak, że ten efekt defamiliaryzacji możliwy jest jednakowoż tylko wówczas, gdy uruchomiony zostanie inny rodzaj widzenia nie perspektywiczne zdystansowane oko/ja, lecz intensywne spojrzenie-zbliżenie uruchamiające także inne zmysły, umożliwiające przepuszczenie grozy obrazu przez czujące ciało obserwatora-świadka.

Widok zza bliska. Inne obrazy Zagłady to tytuł wystawy, która pokazywana była w Muzeum Etnograficznym w Krakowie na przełomie 2018 i 2019 roku. Kuratorami wystawy (będącej częścią projektu naukowego skoncentrowanego na poszukiwaniu wizualnych wypowiedzi artystów o Zagładzie

6. Używam tego terminu za Romą Sendyką: "Inne obrazy Zagłady, Roma Sendyka, Wojciech Wilczyk i Magdalena Zych w rozmowie z Martą Duch-Dyngosz”, Miesięcznik Znak (06/2019), nr 769, 2019, 159 (format epub).

7. “Inne obrazy Zagłady...", 159.

8. Por. Adam Mazur we wspomnianym powyżej tekście, a także Elżbieta Janicka w rozmowie z Krzysztofem Cichoniem: "Portrety powietrza. Z Elżbietą Janicką rozmawia Krzysztof Cichoń", Atlas sztuki. http://www.atlassztuki.pl/pdf/janicka3.pdf (11.10.2019).

9. Używam tego terminu oczywiście w sposób umowny, jednocześnie świadomie odnosząc się do myśli Briana Massumi w kontekście jego połączeniem afektu i taktylności (zob. Brian Massumi, Parables for the Virtual: Movement, Affect, Sensation (Durham and London: Duke University Press, 2002). $\mathrm{W}$ polskiej myśli podejście afektywne w badaniach nad kulturami pamięci eksploruje w licznych tekstach Romy Sendyki. Jednymi z ważniejszych publikacji zbiorowych na ten temat są tomy Pamięć i afekty pod redakcją Zofii Budrewicz, Romy Sendyki i Ryszarda Nycza (Warszawa: Instytut Badań Literackich PAN, 2014) oraz Historie afektywne i polityki pamięci, red. Elżbieta Wichrowska, Anna Szczepan-Wojnarska, Roma Sendyka i Ryszard Nycz (Warszawa: Instytut Badań Literackich PAN, 2015). 
w zbiorach etnograficznych) byli Erica Lehrer, Roma Sendyka, Wojciech Wilczyk i Magdalena Zych. Prezentowane prace artystów nieprofesjonalnych, pochodzące z polskich i niemieckich kolekcji etnograficznych i prywatnych zbiorów, funkcjonują tu na kilku poziomach: jako świadectwa Holokaustu, ale także jako produkty złożonych mechanizmów tworzenia znaczenia na przecięciu skomplikowanych i często sprzecznych emocji, ideologii, narracji historycznych i relacji władzy:

[...] to dzieła, które opowiadają o wojnie, widzianej z bardzo bliskiej perspektywy. Część z nich celowo lub przypadkiem ujęła Zagładę, pokazując ją jako tragedię Żydów, martyrologię Polaków lub uniwersalny dramat ludzkości. Widzimy je jako skomplikowane obiekty złożone z różnych impulsów; ich twórcami są artyści, ale także kolekcjonerzy, etnografowie, kustosze i kuratorzy, ideolodzy $y^{10}$.

Prace pokazywane na wystawie zostały sfotografowane przez Wojciecha Wilczyka i część z tych fotografii ujęta w serię Powiększenia stała się jedną z części ekspozycji. Przeskalowane fotografie wydobywają afektywny aspekt prezentowanych prac, bo niejednokrotnie podążają za spojrzeniem twórcy, świadka i ofiary, ale też wydobywają emocjonalne ślady procesu powstawania prac poprzez zwrócenie uwagi na gest artysty, na przykład żmudnie wypracowującemu konkretne detale nadające portretowanym ofiarom indywidualne rysy ${ }^{11}$. Obecność fotograficznych zbliżeń autorstwa Wilczyka oraz fakt, że wystawa była kuratorowana z tak głęboką krytyczną świadomością mechanizmów ideologicznych i relacji władzy stojących za produkcją i dystrybucją pokazywanych dzieł, sprawiają, że nie sposób dominującego jej przekazu sprowadzić do krzywdzących uproszczeń częstych dla narracji wokół sztuki "naiwnej”, "ludowej”. To właśnie dzięki przeskalowaniu pojawia się przestrzeń na pytania: czy w tych pracach, uwikłanych często przecież w wie-

10. Źródło: opis wystawy na stronie Muzeum Etnograficznego w Krakowie, https://etnomuzeum.eu/wystawy-czasowe/widok-zza-bliska-inne-obrazy-zaglady (17.11.2019).

11. Opisując fotograficzne zbliżenie rzeźby trzech figurek autorstwa Józefa Piłata, Wilczek mówi: "W przypadku rzeźby Józefa Piłata moją uwagę zwróciły twarze trzech figurek. Wiedziony intuicją zrobiłem ich zbliżenia. Nie znałem historii powstania tej pracy. Dopiero potem dowiedziałem się, czytając wspomniany wiersz Tomasza Gajdy oraz opis kustoszki Barbary Erber, że Piłat przedstawił postaci autentyczne. Posługując się konwencją typową dla sztuki naiwnej, nadał wyrzeźbionym postaciom cechy indywidualne, co jest bardzo rzadkie w badanych przez nas pracach. One były na tyle wyraźne, że sąsiedzi Piłata rozpoznali kolejno: Majera Lewesteina, Ruchlę Orzech i Mejlocha Orzecha, mieszkańców Dębskiej Woli. [...] Piłat sportretował Żydów tak, jak ich pamiętał, zrobił jednak coś więcej, niż wymagali kolekcjonerzy czy instytucje zamawiające takie prace. Gdy sięgniemy do biografii artysty, to on specjalnie, o czym Gajda pisze, Żydom chętny nie był, jego żona była antysemitką, zapewne środowisko też było takie. Jednak robiąc tę pracę, dokonał wyraźnej transgresji”. "Inne obrazy Zagłady, Roma Sendyka, Wojciech Wilczyk i Magdalena Zych w rozmowie z Martą Duch-Dyngosz", 166-167. 
le instytucjonalnych i ideologicznych zależności, może pojawić się moment suwerenności, moment spotkania czyjegoś spojrzenia, chwilowa choć relacja "współświadczenia"12?

Choć Wojciech Wilczek mówi: “Interesowali nas artyści, którzy dokonują transgresji - robią coś więcej, niż oczekują zleceniodawcy”'3, to zespół kuratorski Widoków zza bliska... nie daje nam jednak prostych odpowiedzi i nie stawia jednoznacznych tez. Nie pokazuje linii demarkacyjnej między instytucjonalnym uwikłaniem w konteksty władzy, historyczną i polityczną mitologizacją a "autentyczną" emocją i potrzebą współświadczenia tragedii Żydów, mimo że sugeruje możliwość afektywnego potencjału u źródeł powstania niektórych dzieł. Zwłaszcza jedna z części wystawy - ta, do której trafiamy na samym końcu i która porzuca analityczne ambicje - pokazuje kilka prac, które wydają się próbą empatycznego otwarcia się artysty na cierpienie Innego, współodczuwania z konkretnym człowiekiem o indywidualnych rysach, a nie uogólnioną figurą Żyda bądź "ofiary wojny".

Jestem gotowa zaryzykować tezę, że afekt pojawia się nie tylko w części "emocjonalnej" wystawy, lecz także w elementach na pozór silnie skonwencjonalizowanych, "reprezentacyjnych", narracyjnych - w szczelinach wymykających się symbolizacji, z których nagle wyziera materialna podszewka narracji, lewa strona, fizyczna i cielesna baza. To właśnie fotograficzne przeskalowanie niektórych detali w pracach Wilczyka dodaje do naszego postrzegania wymiar intymności, wymiany spojrzeń, ale przede wszystkim - wydobywając strukturę i właściwości użytych materiałów - namacalnie łączy nas z intencjonalnym gestem twórczym.

Uderzającym przykładem uruchomienia afektywnego potencjału dzieła przez wydobycie materialnej i fizycznej warstwy gestu twórczego jest wypowiedź malarza Adama Czarneckiego o genezie jego pracy pt. Żydy do roboty (Fot. 1), która towarzyszyła ekspozycji (jako tekst na wystawie i nagranie głosu artysty). Malarz mówi:

Namalowałem taki ten obraz. Jeden, taki pochmurny, deszczowy. Jak to oni mieli taką krzywdę na tej... Przyjechali do dnia. Nie spodziewali się. To było jeszcze szarówka, ciemno było. No i wszystkich, i wszystkich zabrali. Nie uciekł - nikt. Tak mi to utkwiło w pamięci. Wziąłem, przyjechałem do Pierzchnicy, tak mi to tak jakoś to było niedobrze [...]. Wziąłem i namalowałem. Taką pamiątkę mam. Ten pierwszy obraz to malowałem go w czterdziestym siódmym roku. Nie miałem farb, ale chciałem tak właśnie naturalnie namalować ten obraz. I skąd ja takich farb wezmę? Sam zrobiłem ich z tego popiołu. Wybierałem czerwoną, popielatą, takie granatowe $[\ldots]^{14}$

12. Ten termin zapożyczam od Brachy L. Ettinger: zob. "Wit(h)nessing Trauma and the Matrixial Gaze", w: Bracha L. Ettinger, The Matrixial Borderspace, red. Brian Massumi (Minneapolis-London: University of Minnesota Press, 2006), 123-156.

13. "Inne obrazy Zagłady...", 160.

14. Wypowiedź Adama Czarneckiego w filmie Ślady Andrzeja Brzozowskiego (czerwiec 1967).Źródło: tekst na wystawie Widoki zza bliska. Inne obrazy Zagłady. Muzeum Etnograficzne w Krakowie, 2018/2019. 


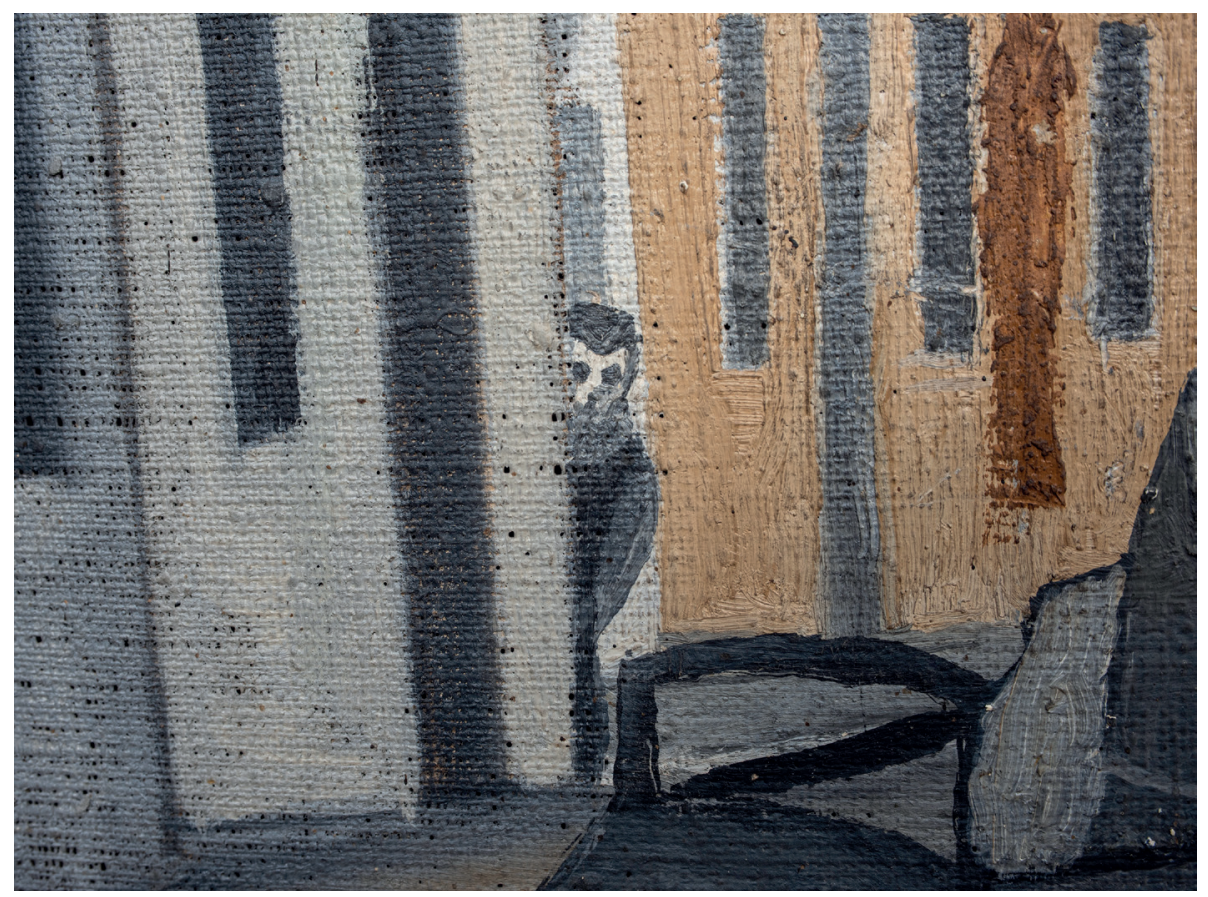

Fot. 1. Fragment obrazu, Adam Czarnecki, Żydy do roboty, 1967, Muzeum Narodowe w Kielcach - fotografia Wojciecha Wilczyka z serii Powiększenia (2016-2018) - dzięki uprzejmości Artysty.

W ramach serii Powiększenia Wojciech Wilczyk wykonał fotografię detalu z obrazu Czarneckiego. Postać świadka obserwującego z ukrycia scenę pojmania grupy żydowskich mieszkańców jest schowana za rogiem budynku i trudno ją dostrzec na oryginalnej pracy. Fotograf przenosi uwagę widza na tę ukrytą a zarazem kluczową postać, której przerażone spojrzenie krzyżuje się na chwilę z naszym. To, co jednak najbardziej uderza na fotografii Wilczyka to fakt, że dzięki przeskalowaniu można dostrzec na płótnie fakturę farby zmieszanej z popiołem.

Narracja kuratorska Widoków zza bliska... robi dokładnie to, co powinna czyli zostawia nas z serią pytań uniemożliwiających jakąkolwiek jednoznaczność ocen: demitologizuje infantylizującą stygmatyzację twórców ludowych jako niewinnych i nierozumiejących świadków szukających dziecięcej ekspresji dla przeżytego horroru, ukazuje wspominane wcześniej mechanizmy ekonomiczne, polityczne, ideologiczne i ekonomiczne powstawania ich prac, a jednocześnie obnaża istniejący w polskim dyskursie narracji o Zagładzie klasizm i tendencje do spychania odpowiedzialności za nieludzkie traktowanie Żydów na klasę 
ludową ${ }^{15}$. Jednocześnie wewnątrz tej narracji tworzy się jednak również mikronarracja, uruchamiana głównie za sprawą fotograficznych zbliżeń Wilczyka, która sugeruje istnienie afektywnej szczeliny istniejącej poza analitycznym porzadkiem wystawy. Moment, w którym powiększenie na fotografii konfrontuje nas z fakturą na płótnie, w którym słuchamy słów Czarneckiego, wyobrażając sobie artystę robiącego farbę z popiołu, sprowadza nas gwałtownie i nieodwracalnie do innego porządku: ziemi, głosu, ciała, ruchu, materii i gestu, w którym nie ma ucieczki od współodczuwania rany. Wzrok przestaje na chwilę służyć paradygmatowi obiektyfikującego spojrzenia, lecz toruje drogę dla "spojrzenia" innymi zmysłami - dotykiem i słuchem, które nie są zmysłami dystansu ja/oko kontra Inny, lecz zmysłami bliskości i zanurzenia we wspólnej przestrzeni postrzegania. To samo przecież robi fotograficzne zbliżenie - nie pozwala nam "złapać perspektywy" koniecznej dla stworzenia dychotomicznego rozdźwięku między podmiotem-okiem patrzącego a przedmiotem poznania.

Kolejnym elementem zbliżania się do rany jest popiół. Ta figura nieobecności i utraty (przywołująca równie silnie zsymbolizowane tropy, takie jak dymy i piece ${ }^{16}$ ) tutaj staje się medium umożliwiającym afektywne połączenie. Nie reprezentacja jest tu ważna, lecz cielesny kontakt $\mathrm{z}$ materią. Z mocno skonwencjonalizowanego, niedotykalnego symbolu śmierci i niebytu, w obrazie Czarneckiego popiół zyskuje dodatkowe znaczenie jako byt materialny, ziemski, fizyczny, otwierający możliwość reprezentacji, ale sam w sobie wymykający się porządkowi znaku. Przygotowanie farby z popiołu jest gestem "zrobienia czegoś więcej". Szorstka faktura mieszaniny, o którą "potyka się" pędzel podczas malowania, to przeciwwaga dla "gładkich" powierzchni szablonowych reprezentacji Zagłady.

Wymowa popiołów jako tropów straty i żałoby, ale także przepracowywania traumy jest dość oczywista, zwłaszcza w kontekście imaginarium kultury żydowskiej ${ }^{17}$. Popioły stały się też w ostatnich kilkunastu latach - głównie za sprawą serii Elżbiety Janickiej Miejsca nieparzyste (2003-2004) metonimią realnej, fizycznej wszechobecności śladów Zagłady w Polsce - tych widzialnych i niewidzialnych, ukrytych pod ziemią, krążących w powietrzu, wmieszanych w obieg materii ożywionej i nieożywionej. Jest to cykl czarno-białych fotografii analogowych. Zdjęcia wyglądają tak samo: sześć białych kwadratów w czarnej ramce kliszy fotograficznej

15. Zob. "Inne obrazy Zagłady...".

16. Takie metonimiczne figury Zagłady zostały utrwalone w warstwie językowej chociażby w takich hasłach-tytułach jak Dymy nad Birkenau Seweryny Szmaglewskiej czy Epoka pieców Adolfa Rudnickiego. Jednocześnie to właśnie komin staje się zikonizowanym wizualnym tropem obozu w Auschwitz.

17. Słowo רְפּ (efer) używane jest zarówno w kontekście żałoby, jak i utraty, nicości, braku (popiół i pył). Zob np. Morris Jastrow, "Symbols of Mourning among the Ancient Hebrews", Journal of the American Oriental Society, no. 20, 1899, s. 133-150. 
AGFA $^{18}$ opatrzonych tytułami z nazwą obozu i liczbą ofiar (Fot. 2). Zdjęcia z pozoru wydaję się dokumentować pustkę lub niebo. W rzeczywistości przedstawiają powietrze nad miejscami, w których znajdowały się obozy zagłady - powietrze, w którym wciąż krążą cząstki popiołów (już nie tych "metonimicznych", ze spalonego drewna czy węgla, lecz ludzkich prochów), wprzęgnięte w nieustanny cykl przyrody, unoszone przez wiatr, krążące w podziemnych wodach, zatrzymane w chmurach, spływające z deszczem.

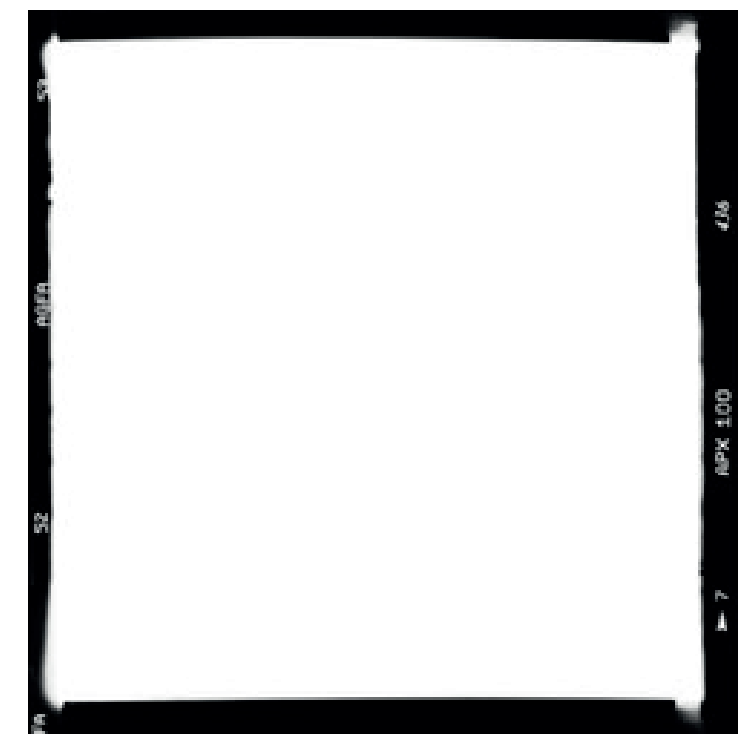

Fot. 2. Elżbieta Janicka, fotografia z serii Miejsca nieparzyste (2003-2004) - dzięki uprzejmości Artystki.

Janicka w swoich tekstach i projektach skupia się na tym, co Kornelia Sobczak nazywa "splotem materialności" ${ }^{19}$. Popioły są dla niej materialnym śladem wpisanym w cielesne doświadczenie przestrzeni, powietrza, ale także śladem przemysłowych mechanizmów Zagłady. Nieprzypadkowo korzysta $\mathrm{z}$ fotografii analogowej, która - jak podkreśla - "cała jest materialnością", ponieważ "polega na kontakcie materii z materią za pośrednictwem materii [... ]. W tym sensie fotografia abstrakcyjna nie istnieje. Fotografia analogowa jest zawsze materialnym

18. Janicka mówi: “Obrazy Zagłady, które mamy przed oczami, ponieważ stały się częścią otaczającej nas ikonosfery, to przede wszystkim AGFA". "Portrety powietrza. Z Elżbietą Janicką rozmawia Krzysztof Cichoń”, Atlas sztuki, http://www.atlassztuki.pl/pdf/janicka3.pdf (11.10.2019).

19. Kornelia Sobczak, "Gaz”, w: Ślady Holokaustu w imaginarium kultury polskiej, 180. 
śladem"20. Choć pozornie fotografie Janickiej wpisują się w estetykę minimalistcznej symbolizacji (przez co mogą przywodzić na myśl abstrakcyjne obrazy), w rzeczywistości są fizycznym "odciskiem” cząstek krążących w powietrzu w fotografowanych przestrzeniach: "Przyszło mi jednak do głowy, że otwierając migawkę na dłużej można tego powietrza całkiem sporo nałapać do wnętrza aparatu i ono się jakoś na kliszy odciśnie. Chciałam uzyskać taki odcisk" ${ }^{21}$. W tym aspekcie praca Janickiej jest odpowiedzią na sublimacyjną konwencję reprezentacji Zagłady, która ucieka od materialności martwych ciał w symbolizację. A popioły - ludzkie prochy - przecież są pod spodem, stanowią materialną i dotykalną tkankę macierzystą, budulec i podskórny nawóz dla symbolicznych strategii porządkowania rzeczywistości: tej wyobrażeniowej ${ }^{22}$ i tej realnej - popioły z ludzkich szczątków użyźniają pola i łąki, mieszają się z budulcem, z którego powstają powojenne osiedla. Tym, co wyróżnia pracę Janickiej (traktowaną tu jako całość: jako fotografie i zbudowaną wokół nich narracje), jest szokująca konfrontacja z realnością pozostałości Zagłady przedzierającą się przez papierowe warstwy symbolizacji:

Kraj mojego urodzenia. Wizja lokalna nie pozostawia wątpliwości. Grzyby. Poziomki. Ptaki. Świerszcze. Lasy i łąki. Żywiczne zapachy. Bociany. Mleczne krowy. Miodne pszczoły. O świcie i o zmierzchu ziemia paruje pod słońce. Zimą sarny. W śniegu trop zajęcy. Powietrze. Dużo powietrza. Krajobraz. Made in Poland. "Dobre, bo polskie". "Teraz Polska”. Taki mamy znak firmowy. I złoża ludzkich prochów. Pokłady Żydów poddanych przetwórstwu i utylizacji. Krążąa Już bez przeszkód. W ziemi. W wodzie. W ogniu. W powietrzu. Często zupełnie na wierzchu, ale zawsze jakby pod spodem. $\mathrm{Na}$ rewersie bukolicznego landszaftu ${ }^{23}$.

W rozmowie z Krzysztofem Cichoniem Janicka nie szczędzi drastycznych obrazów "ziemi wymiotującej trupami w rozkładzie", "spuchniętego, gnijącego i ociekającego cieczami mięsa" zsuwającego się po zboczu wzniesienia, na którym położony jest obóz w Bełżcu, mechanizmów produkcji i utylizacji zwłok - wyciągania z samochodów i komór rękami lub hakami, rozrąbywania, dźwigania, ciągnięcia, upychania w dołach, palenia, psujących się i zapychających krematoriów,

20. "Portrety powietrza. Z Elżbietą Janicką rozmawia Krzysztof Cichoń”... (11.10.2019). Zob. też Kornelia Sobczak, “Gaz...”, 180.

21. "Portrety powietrza. Z Elżbietą Janicką rozmawia Krzysztof Cichoń”... (11.10.2019).

22. Wystarczy wspomnieć Odczytanie popiołów Ficowskiego czy Fun asz arojsgerufn / Cienie z popiołów Daniela Katza, Gorący popiół Jastruna, Medaliony Nałkowskiej - pisane kiedy jeszcze nie ostygły popioły wojny - liczne odniesienia do popiołów u Irit Amiel, Paula Celana i Awroma Suckewera, Popioły i diamenty Grynberga i wiele innych.

23. Elżbieta Janicka, "Hortus Judeorum. Refleksje oddechowo-trawienne na marginesie pracy Miejsce nieparzyste”, w: Imhibition, red. Roman Dziadkiewicz, Ewa Małgorzata Tatar (Kraków: Muzeum Narodowe w Krakowie, 2006), 99. 
młynków do mielenia kości mielących te kości za grubo (nie na "proch i pył”), wykopywania zwłok po upływie miesięcy, ponownego ciągnięcia i dźwigania, odpadających głów i kończyn, upychania na stosach, palenia, znów mielenia spalonych szczątków ${ }^{24}$. Ten szczegółowy i konkretny obraz nie ma na celu epatowanie horrorem. Nawet przytaczając go, trudno pominąć którykolwiek z użytych czasowników i rzeczowników, bo to trochę tak, jakby ominąć wzrokiem to, czemu należy się bezwzględne uznanie i zauważenie. Janicka zresztą podkreśla to w swojej wypowiedzi, pośrednio potwierdzając status tego opisu jako brakującego wtórnego świadectwa:

No więc dociera człowiek na miejsce, a tam jest... Są zioła i kwiaty. Grzyby, jagody, jeżyny, maliny, poziomki, motyle i ptaki, pszczoły i świerszcze. Zaskrońce wygrzewające się leniwie na słońcu. Opadające lub wstające mgły. Balsamiczne aromaty. Czyste niebo albo niebo z chmurami. Słońce i księżyc, planety i gwiazdy. Zieleń, zieleń i zieleń. To są miejsca piękne, dobre, bezpieczne - figury raju po prostu. I komunikat jest jeden: "Nic się nie stało. Wszystko w porządku”. Oczywiście dopóty, dopóki człowiekowi nie wejdzie w ciało drzazga z ludzkiej kości ${ }^{25}$.

Popioły związują się nieodwracalnie ${ }^{26} \mathrm{z}$ tkanką zarastającą ziemię, w której spoczywają szczątki: zasilają wegetację dzikich roślin, a w niektórych miejscach wrastają nieodwracalnie w tkankę miejską - szczególny jest na przykład status warszawskiego Muranowa zbudowanego z gruzobetonu "ze szczątków domów i ludzi”27, o którym również pisze Janicka ${ }^{28}$.

Wydaje się, że krążące w powietrzu, wodzie i ogniu popioły są tu ikonicznym znakiem nie tylko wszechobecności śladów Zagłady w przestrzeni, w której żyje$\mathrm{my}^{29}$, lecz także niemożności domknięcia śmierci zarówno na poziomie rytualnym, jak i fizycznym. Joanna Krakowska pisze:

Zagłada wyłączyła śmierć z semantycznego pola wytyczanego przez cmentarz, zerwała jej związki ze słowami: "pogrzeb”, "pochówek”, "całun”, “żałobnicy”, "kadysz”, "grób”,

24. "Portrety powietrza. Z Elżbietą Janicką rozmawia Krzysztof Cichoń”... (11.10.2019).

25. "Portrety powietrza. Z Elżbietą Janicką rozmawia Krzysztof Cichoń”... (11.10.2019).

26. Janicka mówi: "Myśli się też o idei Endlösung - ostatecznego rozwiązania, którego rezultatem stało się ostateczne związanie. Prochy wykluczonych mamy dzisiaj w ziemi, w wodzie i w powietrzu, których im za życia odmówiono", “Portrety powietrza. Z Elżbietą Janicką rozmawia Krzysztof Cichoń”... (11.10.2019).

27. Izabela Szymańska, "Sylwia Chutnik o duchach Muranowa", Gazeta Wyborcza, 10 maja 2012, cytat za: Joanna Krakowska, “Cmentarz”, Ślady Holokaustu w imaginarium kultury polskiej, red. Justyna Kowalska-Leder, Paweł Dobrosielski, Iwona Kurz i Małgorzata Szpakowska, 113.

28. Zob. Elżbieta Janicka, Festung Warschau (Warszawa: Wydawniwctwo Krytyki Politycznej, 2011).

29. Por. Justyna Janicka-Leder, "Wstęp”, w: Ślady Holocaustu..., 21. 
“ohel”. W zamian zaoferowała własne konteksty freazologiczne: “wagon”, “gaz”, “komin”, "popioły" $[\ldots]^{30}$.

Popioły są tu więc metonimią rozproszenia. Roma Sendyka, definiując nie-miejsca pamięci, wskazuje na "obecność szczątków ludzkich, niezneutralizowanych rytuałami pochówku” oraz przemieszanie porządku organicznego (szczątki ludzkie, rośliny, zwierzęta) z nieorganicznym. W nie-miejscach pamięci ofiary nie są upamiętnione indywidualnie, lecz mają tożsamość grupową, zwykle inną niż lokalna społeczność ${ }^{31}$. Rolą rytuału pochówku jest, jak pisze dalej Sendyka, "oddzielenie," "zasklepienie" czy "zabezpieczenie". Ustanowienia fizycznej bariery między żywymi i umarłymi jest w wielu kulturach obowiązkiem, którego niedopełnienie ma skutkować obecnością “widma” nękającego żyjących ${ }^{32}$.

Popioły stają się zatem figurą nieoddzielenia, rozsypania, bezkształtności i wymieszania porządków. Przywodzą na myśl nieuporządkowaną strukturę traumy będącą rozproszonym w ciele doświadczeniem, które - niepoddane procesowi narracyjnej obróbki - nie może zostać zapieczętowane w kapsule reprezentacji ${ }^{33}$. To wyprzęgnięcie z porządku znaku skazuje traumatyczne zdarzenie na zapętlenie $\mathrm{w}$ ciągłym przymusie powrotu ${ }^{34}$. Popioły niezamknięte $\mathrm{w}$ grobie nie pozwalają domknąć procesu żałoby. Parafrazując teorię traumy Marii Torok i Nicolasa Abrahama, można powiedzieć, że śmierć, która nie została przepracowana przez rytuał przejścia (niezamknięta w grobie), zamiast tego zostaje zamknięta w krypcie nieświadomości jako widmo, do którego podmiot nie ma dostępu, choć przysparza ono podmiotowi cierpień ${ }^{35}$. Dominick LaCapra podkreśla, że również w praktykach pamięci zbiorowej trauma, jeśli nie może zostać przepracowana (worked through), musi być odtwarzana w procesie mechanicznego i przymusowego powtarzania (acting out $)^{36}$. Niczym ciągły powrót nieprzepracowanej traumy obieg popiołów w przestrzeni siłą rzeczy oddziałuje na współzamieszkujących tę przestrzeń, absorbujących krążące w powietrzu, wodzie i glebie szczątki "zewsząd i na różne sposoby" - w ten sposób, jak pisze Janicka, sami stajemy się sarko-

30. Krakowska, “Cmentarz”, w: Ślady Holokaustu..., 103.

31. Roma Sendyka, "Miejsca, które straszą (afekty i nie-miejsca pamięci)", w: Pamięć i afekty, red. Zofia Budrewicz, Roma Sendyka i Ryszard Nycz (Warszawa: Instytut Badań Literackich PAN, 2014), 286.

32. Sendyka, "Miejsca, które straszą...”, 301.

33. Zob. np. Shoshana Felman i Dori Laub, Testimony: Crisis of Witnessing in Literature, Psychoanalysis and History (New York: Routledge, 1992), 69.

34. Zob. Sigmund Freud, "Przypominanie, powtarzanie i przepracowanie", w: Zygmunt Freud. Człowiek i dzieło, red. Krzysztof Pospiszyl (Wrocław: Ossolineum, 1991), 266-273.

35. Zob. Nicolas Abraham i Maria Torok, Cryptonymie. Le verbier de l'homme aux loups (Paris: Flammarion, 1976).

36. Dominick LaCapra, “Trauma, Absence, Loss”, w: Critical Inquiry nr 4, 1999, 696-727. 
fagami ${ }^{37}$. Janicka skupia się na fizycznych przepływach, inkorporacji prochów, na procesie, który można by opisać w kategorii Deleuzjańsko-Guattariańskiego asamblażu elementów ludzkich i nieludzkich, albo przepływów molekularnych ${ }^{38}$ :

W powietrzu krążą popioły. My tym powietrzem oddychamy. A wiatr, chmury, deszcz, Popioły są w ziemi, w rzekach, na łąkach i w lasach - poddawane nieprzerwanemu recyklingowi, w którym uczestniczymy, nie ruszając się z miejsca zamieszkania, kupując w osiedlowym spożywczym ser żółty ze spółdzielni mleczarskiej w Kosowie Lackim, miód z tamtych terenów czy sos tatarski z Wizny. Bo tam się pasą zwierzęta ${ }^{39}$.

Ta ciągła absorpcja, przepływ, fluks czy też asemblaż, siłą rzeczy przenosi nasze doświadczenie na poziom ponadpodmiotowy. Podobnie jak w narracyjnym porządku przedstawienia w obrazie Adama Czarneckiego popiół domieszany do farby jest rewersem konwencjonalnie sformatowanej reprezentacji obrazu (i to on stanowi dotykalny afektywny łącznik między współświadczonym wydarzeniem a dotykającym, nieobiektywizującym spojrzeniem artysty), tak i realność ludzkich popiołów u Janickiej staje się tropem, który odnosi nas do transpodmiotowego aspektu śladów Zagłady. Ten potencjał połączenia czy otwarcia się na ślady traumy Innego rodzi możliwość, a wręcz konieczność podjęcia prób przepracowywania nieswojej straty. Janicka mówi o konieczności i zarazem niemożności wyrażenia grozy Holokaustu, próbie objęcia spojrzeniem straty, próbie sprostania roli sarkofagu $^{40}$. Psychonalityczka i artystka Bracha Ettinger nazywa ten nieunikniony proces transkryptum - niesieniem śladów traumy Innego i przetwarzaniem jej w akcie estetycznym, które zyskuje wymiar etyczny. Transkryptum jest więc przepisaniem krypty, funkcją pamięci w procesie tworzenia dzieła sztuki i dotyczy traumy Innego, znanego lub nieznanego. W procesie ucieleśnienia transkrypcji traumy dokonuje się proces wzajemnej inskrypcji jej śladów ${ }^{41}$. Dla Ettinger sztuka jest spotkaniem-wydarzeniem, przestrzenią samorozkruszania, w której artyst(k)a dotyka niedokonanych przyszłości Innych i w ten sposób spotyka ich spojrzenie ${ }^{42}$ stając się współ-świadkinią (wit[h]ness) ich traumy.

37. “Portrety powietrza. Z Elżbietą Janicką rozmawia Krzysztof Cichoń”... (11.10.2019).

38. Zob. Tysiac plateau. Kapitalizm i schizofrenia 2, red. Joanna Bednarek, tłum. Sławomir Królak, Piotr Laskowski i Mateusz Janik (Warszawa: Fundacja Nowej Kultury Bęc Zmiana, 2015).

39. “Portrety powietrza. Z Elżbietą Janicką rozmawia Krzysztof Cichoń”... (11.10.2019).

40. "Portrety powietrza. Z Elżbietą Janicką rozmawia Krzysztof Cichoń”... (11.10.2019).

41. Bracha L. Ettinger, “Transkryptum: tropienie śladów pamięci z/w/z myślą o Innym”, przeł. Anna Chromik, Anna Kisiel, w: Narracje o Zagładzie nr 2, 2016, 107.

42. Bracha L. Ettinger, "Fragilization and Resistance", w: Studies in the Maternal t. 2, nr 1, 2009, https://www.researchgate.net/publication/286320274_\%27Fragilization_and_Resistance\%27_and_\%27Neighborhood_and_Shechina\%27 (2.11.2019). 


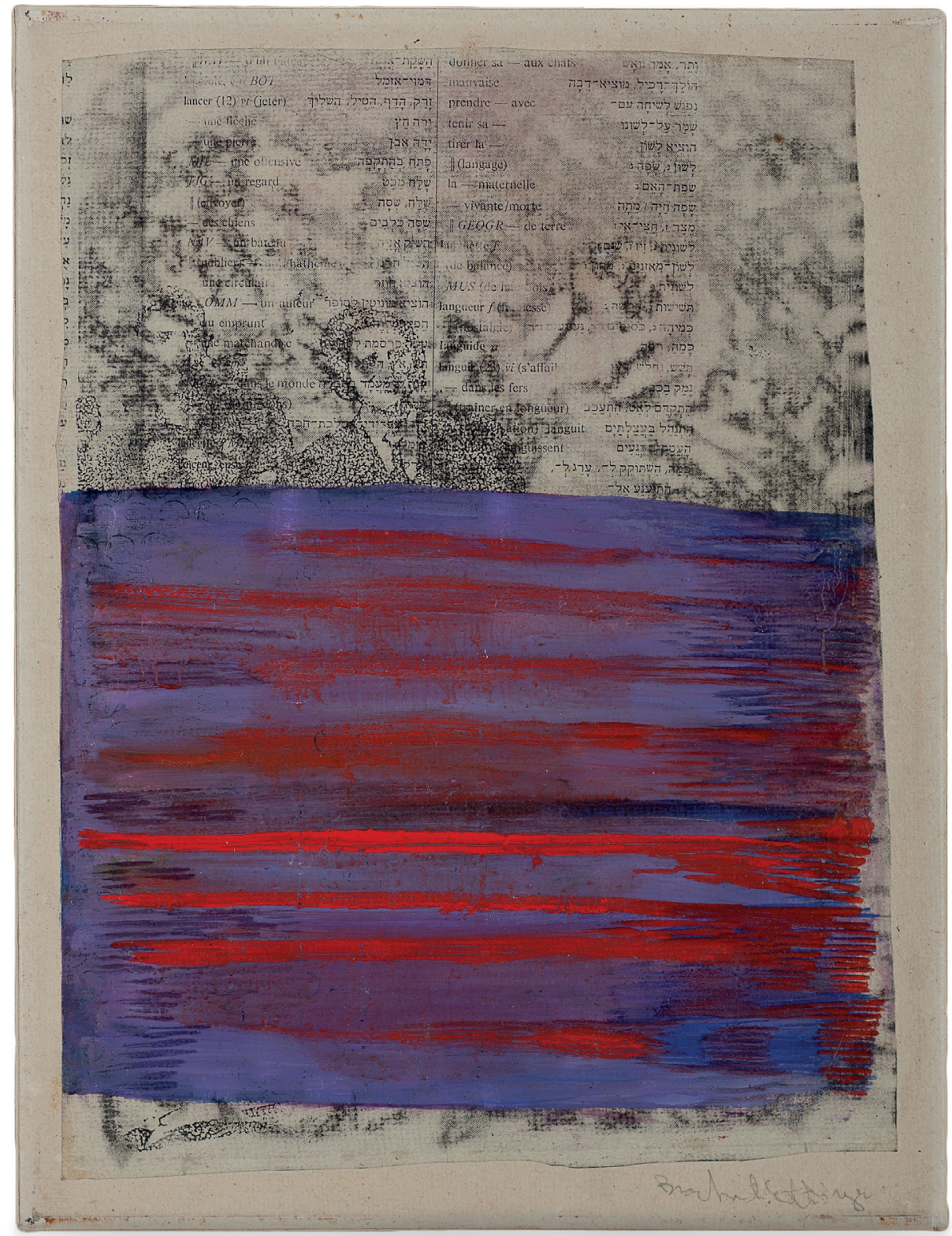

Fot. 3. Bracha L. Ettinger, Eurydice No. 4, 1992-1994, olej, kserokopia z pigmentem i popiołem na papierze naklejonym na płótno, $36,8 \times 27 \mathrm{~cm}$; reprodukcja dzięki uprzejmości Artystki (oil, xerography with photocopic pigment and ashes on paper mounted on canvas; copyright courtesy of the Artist). 
Popiól, proch i fotografia naznaczają zresztą też wyraźnie swą obecność w twórczości Ettinger. Wiele z jej prac malarskich to różnorakie formy interwencji w fotografie archiwalne lub rodzinne dokumentujące wprost zbrodnie Holokaustu lub będące świadectwem strat związanych z Szoa ${ }^{43}$. Artystka często zatrzymuje fotokopiarkę $\mathrm{w}$ trakcie procesu kopiowania, dzięki czemu pył $\mathrm{z}$ tonera osiada na papierze $\mathrm{w}$ formie delikatnych zarysów powielanego obrazu, a następnie zamalowuje fotografie bądź ich fragment farbą, często zmieszaną z popiołem bądź pyłem $\mathrm{z}$ tonera, której kolejne warstwy tworzą efekt hologramu. To "tworzeniu śladu" jest u Ettinger procesem, który łączy plastyczność obrazu z przepracowywaniem traumy własnej i traumy Innego. W swych pracach Ettinger otwiera przestrzeń spotkania pomiędzy postaciami z fotografii (często są to ofiary Szoa, kobiety i dzieci zamordowane lub poszkodowane w wyniku wojennej przemocy) a teraźniejszością śladu przepuszczonego przez materialne medium światła i tonera, papieru, farby, pigmentu, pyłu, popiołu i ciała artystki. Artystka przetwarza ślady traumy przez materialność, zarówno we własnym ciele i poprzez nie, jak i poprzez fizyczność użytych materiałów"44 - farb, pyłu-popiołu, pigmentu, wody - dokonując tym samym reinskrypcji rany w obszar znaczenia, choć nie jest to znaczenie spoza binarnej logiki fallicznego znaku.

Gest artysty/artystki, który/która sięga ku popiołom jest zawsze gestem zanurzenia w materialności. Popiół (ze spalonego drewna czy innych materiałów), choć naznaczony mocnym symbolicznym ładunkiem, może tu być - jak u Czarneckiego - "przypadkowym" materiałem nadającym określony kolor i fakturę użytym farbom, dającym swoisty opór pociągnięciom pędzla, a jednocześnie bardzo znaczącym przez sam gest, intencję i wysiłek przygotowania farby z tym medium. Jeśli w tym geście pojawia się próba dania świadectwa, to uwidacznia się ona dopiero, gdy wydobędzie ją z popielatego tła przeskalowana fotografia. Gest ten może być - jak u Janickiej i Ettinger - próbą połączenia się z raną nieznanego Innego po to, by uznać jego traumę i w pewien sposób fizycznie przepuścić ją przez własne somatyczne doświadczenie, nawiązać nić spotkania. Jeśli drobiny popiołów pomordowanych Żydów krążą w naszym powietrzu, wodzie, krwioobiegach i tkwią pod naszymi powiekami, to przepracowanie ich w twórczym procesie (który jest zarazem fizycznym i materialnym gestem), naświetla je i wywołuje z mroku ich kształty. Być może dopiero artyści drugiego i trzeciego pokolenia są w stanie dotknąć grozy materialności śmierci w afektywny sposób bez konieczności uruchamiania

43. Zob. Anna Chromik, "Dotyk, rytm i współświadczenie. O afektywnym potencjale materialności i taktylności w twórczości Brachy Ettinger”, w: Widok. Teorie i Praktyki Kultury Wizualnej, nr 23, 2019, http://www.pismowidok.org/pl/archiwum/2019/23-sila-kobiet/dotyk-rytm-i-wspolswiadczenie (2.12.2019).

44. Źródło: korespondencja własna $\mathrm{z}$ artystką, marzec 2017. 
ochronnych mechanizmów symbolizacji odgradzających od makabry naznaczonej groźbą dezintegracji własnej podmiotowości, lecz uniemożliwiających również przepracowanie traumy i przejście żałoby. Nie da się tego zrobić przez kontakt z nachalną symbolizacją abstrakcyjnych metafor. Proces ten wymaga praca $\mathrm{w}$ innym porządku, w połączeniu $\mathrm{z}$ doświadczeniem cielesnym umożliwiającym współświadczenie i współodczuwanie z cierpiącym ciałem Innego, który musi zostać dotknięty - przez uprzedmiotawiające spojrzenie obiektywu, dłoń mieszającą farbę z popiołem lub kliszę, która złapie odcisk jego cząstek wpadających przez otwartą migawkę.

Być może to, czego najbardziej teraz potrzebujemy w kontekście upamiętnienia Holokaustu jest jej konkretyzacja umożliwiająca afektywny dostęp do czującej (choć nie czułostkowej) pamięci. Eksperymentalne techniki artystyczne wykorzystujące fotografię zdają się mieć w sobie potencjał uruchamiania najbardziej dotykalnego, namacalnego doświadczania śladów Szoa, które - choć często przezroczyste, niewidzialne bądź ukryte - wciąż są obecne w naszym polu wizualnym i taktylnym. Skupienie na fakturze materiału plastycznego, fizyczność gestu artystycznego, nagle uświadomiona realność cielesnego wymiaru Zagłady zawierają w sobie możliwość przemiany artysty i widza w "czującego świadka" bądź "współświadka". By mogło się to wydarzyć, uprzedmiotawiające spojrzenie musi stać się spojrzeniem, które dotyka i czuje. 


\section{Bibliografia}

Chromik, Anna. "Dotyk, rytm i współświadczenie. O afektywnym potencjale materialności i taktylności w twórczości Brachy Ettinger”. Widok. Teorie i Praktyki Kultury Wizualnej nr 23, 2019, http://www.pismowidok.org/pl/archiwum/2019/23-sila-kobiet/ dotyk-rytm-i- wspolswiadczenie (2.12.2019).

Ettinger, Bracha L. The Matrixial Borderspace, red. Brian Massumi, 123-156. Minneapolis-London: University of Minnesota Press, 2006.

Ettinger, Bracha L. 2016. “Transkryptum: tropienie śladów pamięci z/w/z myślą o Innym”, przeł. Anna Chromik, Anna Kisiel. Narracje o Zagładzie 2, 2016, 103-112.

Ettinger, Bracha L. "Fragilization and Resistance". Studies in the Maternal nr 1 (2), 2009, https://www.researchgate.net/publication/286320274_\%27Fragilization_and_Resistance\%27_and_\%27Neighborhood_and_Shechina\%27 (2.11.2019).

"Inne obrazy Zagłady, Roma Sendyka, Wojciech Wilczyk i Magdalena Zych w rozmowie z Martą Duch-Dyngosz". Miesięcznik Znak (06/2019), nr 769, 2019, 154-183.

Janicka, Elżbieta. "Hortus Judeorum. Refleksje oddechowo-trawienne na marginesie pracy Miejsce nieparzyste". W: Imhibition, red. Roman Dziadkiewicz, Ewa Małgorzata Tatar, 99-109. Kraków: Muzeum Narodowe w Krakowie, 2006.

Kowalska-Leder, Justyna, Paweł Dobrosielski, Iwona Kurz, Małgorzata Szpakowska, red. Ślady Holokaustu w imaginarium kultury polskiej. Warszawa: Wydawnictwo Krytyki Politycznej, 2017.

Krakowska, Joanna. “Cmentarz". W: Ślady Holokaustu w imaginarium kultury polskiej, red. Justyna Kowalska-Leder, Paweł Dobrosielski, Iwona Kurz, Małgorzata Szpakowska, 173-194. Warszawa: Wydawnictwo Krytyki Politycznej, 2017.

LaCapra, Dominick. “Trauma, Absence, Loss”. Critical Inquiry nr 4, 1999, 696-727.

Mazur, Adam. "Negatywne świadectwo. Fotograficzna konkretyzacja pamięci Holokaustu". Teksty Drugie nr 5, 2004, 207-213.

"Portrety powietrza. Z Elżbietą Janicką rozmawia Krzysztof Cichoń”. W: Atlas sztuki http://www.atlassztuki.pl/pdf/janicka3.pdf (11.10.2019).

Sendyka, Roma. "Miejsca, które straszą (afekty i nie-miejsca pamięci)". W: Pamięć i afekty, red. Zofia Budrewicz, Roma Sendyka i Ryszard Nycz, 15-22. Warszawa: Instytut Badań Literackich PAN, 2014.

Sobczak, Kornelia. “Gaz”. W: Ślady Holokaustu w imaginarium kultury polskiej, red. Justyna Kowalska-Leder, Paweł Dobrosielski, Iwona Kurz, Małgorzata Szpakowska, 173-194. Warszawa: Wydawnictwo Krytyki Politycznej, 2017.

Szymańska, Izabela. "Sylwia Chutnik o duchach Muranowa”. Gazeta Wyborcza, 10 maja 2012. 